Материалы и методы исследования. Проведен аналитический обзор информационных источников. Методы исследования: информационные.

Результаты и их обсуждение. По результатам анализа информации показана необходимость внедрения на предприятиях спиртовой промышленности адекватных технологий переработки и утилизации основного отхода спиртзаводов - послеспиртовой барды, что связано с ухудшением экологической ситуации на объектах спиртовой промышленности.

\title{
THE INTRODUCTION OF ADVANCED TECHNOLOGIES FOR THE DISPOSAL OF WASTE ON THE OBJECTS OF THE ALCOHOL INDUSTRY IS THE KEY TO PRESERVING THE ENVIRONMENT
}

The Objective: the search and determination of methods of disposal and recycling of industrial waste bards.

Materials: an analytical review of information sources. Research methods: informational.

Results. According to the results of the analysis of information, the necessity of introducing adequate technologies for the processing and utilization of the main waste of the distillery - distillery dregs, which is associated with the deterioration of the ecological situation at the facilities of the alcohol industry, is shown at the enterprises of the alcohol industry.

УДК 614.71:667.621.3

\section{ЕКОЛОГО-ГІГІСНІЧНІ АСПЕКТИ ФУНКЦІОНУВАННЯ АСФАЛЬТОБЕТОННИХ УСТАНОВОК В УКРАЇНІ В СУЧАСНИХ УМОВАХ ГОСПОДАРЮВАННЯ}

\author{
Коваль Н.М. \\ ДУ «Інститут громадського здоров’я ім. О.М. Марзєєва НАМН України», м. Київ
}

Вигідне географічне розташування України на шляху основних транзитних потоків між Європою та Азією, розгалужена мережа автомобільних доріг створюють усі необхідні передумови для збільшення обсягів транзиту країною вантажів. На сучасному етапі транспортна галузь держави потребує комплексного підходу в розвитку, а якість дорожніх сполучень як була, так i лишається для України надзвичайно гострою й актуальною проблемою сьогодення, яка відчувається на різних рівнях споживачів.

Транспортна галузь за багатьма параметрами не відповідає потребам суспільства та європейським стандартам, що перешкоджає підвищенню ефективності іiі функціонування, відтак потребує невідкладних дій щодо їі модернізації.

Мережа автомобільних шляхів України загального користування налічує загалом
169,5 тис. км доріг, з них 3 твердим покриттям - 165,8 тис. км (без урахування муніципальних, відомчих, внутрішньо господарських) [1].

В Україні розроблені цільові програми 3 фінансування великих об'єктів дорожнього господарства, зокрема доріг державного та міжнародного значення. Програми підтримуються вищим керівництвом держави. Оскільки проблема ремонту і будівництва доріг - комплексна, для ii вирішення необхідна потужна сировинна база, яку здатні забезпечити вітчизняні підприємства 3 виробництва асфальтобетонних сумішей [2].

Відповідно до санітарної класифікації виробництв та підприємств додатку №4 до ДСП 173-96 «Державні санітарні правила планування та забудови населених пунктів» (затверджені наказом MO3 України від 
19.06.1996 р. №173 та зареєстровані в Мінюсті України 24.07.2006 р. за №379/1404) [3], асфальтобетонні підприємства віднесені до виробництв будівельної промисловості I класу, для яких визначена нормативна санітарно-захисна зона (далі - С33) до об'єктів житлової та прирівняної до неї забудови розміром 1000 м. Проте, в теперішніх умовах господарювання, враховуючи необхідні умови логістики при виробництві асфальтобетонних сумішей та доріг, де вони використовуються, практично не можливо забезпечити дотримання цього нормативу.

Санітарними нормами С 245-71 «Санитарные нормы проектирования промышленных предприятий» (до 1996 р. - рік введення в дію [3]), для АБЗ нормативна С33 була визначена розміром $300 \mathrm{M}$.

У цьому зв'язку, метою роботи було проведення аналізу містобудівних умов розміщення асфальтобетонних заводів (далі АБЗ) та рівнів шкідливих чинників впливу на безпеку життєдіяльності населення і якість довкілля, які створюються під час експлуатації АБЗ.

Матеріали і методи. Були проаналізовані параметри технології виробництва асфальтобетонної суміші на мобільних асфальтозмішувальних установках (далі - АЗУ), яка реалізовувалась на АЗУ: типу «ТВА 4000», виробництва компанії «BENNINGHOVEN $\mathrm{GmbH} \& \mathrm{Co.KG»,} \mathrm{Німеччина,} \mathrm{потужністю}$ 23,1 тис. т асфальтобетонної суміші на рік (місце розташування виробничих потужностей - Черкаська область); Amman Global-160, виробництва Німеччина, потужністю 50 тис. т/рік (місце розташування виробничих потужностей - Волинська область); типу GLOBAL виробництва фірми «WIBAU» (Hiмеччина), потужністю 50 тис. т/рік (місце розташування виробничих потужностей Волинська область).

Для проведення санітарно-гігієнічної оцінки рівнів впливу, які створюються на межі С33 виробництва, були проаналізовані результати інструментальних досліджень проб атмосферного повітря, вимірювань акустичного впливу, а також результати розрахунку розсіювання валових викидів забруднювальних речовин від їх джерел викидів, що формують сумарний валовий викид по проммайданчику. Протоколи досліджень бу- ли надані спеціалізованими лабораторіями, атестованими на цей вид діяльності.

Результати досліджень. Аналіз умов розміщення вказаних АЗУ виявив, що вказане обладнання 3 допоміжними технологічними дільницями як правило розміщується на проммайданчиках, на яких ще 3 радянських часів функціонували подібні за профілем підприємства, які на теперішній час відновили або відновлюють свою діяльність шляхом модернізації (до повної заміни обладнання) існуючих виробничих потужностей. Враховуючи катастрофічний стан дорожнього покриття як автомобільних доріг, так і внутрішніх в населених пунктах, функціонування таких підприємств є вкрай важливим.

За результатами аналізу, жоден проммайданчик не задовольняв вимог додатку №4 до [3], оскільки за період організації цих виробництв до теперішнього часу змінились містобудівні умови, за яких не можливо організувати С33 розміром 1000 м. У містобудівних умовах, що історично склались, вказані вище АЗУ знаходяться на проммайданчиках, які або з усіх сторін оточені існуючою малоповерховою (одно-, двоповерховою) житловою забудовою (Волинська обл.), або ця забудова розміщується в окремих напрямках світу на відстані меншій 300 м (Черкаська та Волинська обл.).

На сучасному етапі у виробництві асфальтобетонних сумішей використовуються готові бітуми без використання компаундних в'яжучих на основі продуктів коксохімії, що суттєво впливає як на обсяги, так і на спектр викидів забруднювальних речовин під час функціонування АБЗ [4]. Як правило, на підприємствах використовують бітум нафтовий дорожній в'язкий БНД 60/90 (відповідає ДСТУ 4044-2001 «Бітуми нафтові дорожні в'язкі. Технічні умови»), виробництва ПАТ «Укртатнафта»; бітум дорожній марки 70/100, ТУ ВY 400091131.009.2011 СТБ ЕN 12591-2010 (EN 12591:2009), виробництва ВАТ «Мозирський НПЗ», РБ.

Слід зазначити, що АЗУ виробництва Німеччини, що розглядаються, зарекомендували себе на ринку виробництва асфальтобетону за рівнями впливу на навколишнє природне середовище як високоефективне обладнання, яке не створює наднормативних показників за основними шкідливими чин- 
никами (вміст забруднювальних речовин в атмосферному повітря та рівнями шуму).

Зокрема, мобільна АЗУ типу «ТВА 4000», компанії «BENNINGHOVEN $\mathrm{GmbH \& Co.KG»,} \mathrm{Німеччина,} \mathrm{розроблена} 3$ впровадженням нової технології за екологічними параметрами та відповідає екологічним стандартам країн - світових лідерів та системі міжнародних стандартів ISO щодо вимог використовувати «найкращу доступну технологію», яка існує на даний час у світі. За наданою інформацією компанією «BENNINGHOVEN GmbH\&Co.KG» (Німеччина), «Об'єднанням німецьких інженерів» було підтверджено, що викиди пилу від пиловловлюючого обладнання АЗУ знаходиться на рівні не вище $20 \mathrm{mr} / \mathrm{M}^{3}$, що не перевищує нормативи по питомих викидах.

На цих АЗУ основні джерела викидів забруднювальних речовин обладнані пилогазоочисними установками, що суттєво зменшує навантаження на повітряне середовище (до 99\% ефективність по вловлюванню пилу). В технологічному процесі виготовлення асфальтобетону передбачено повернення вловленого пилу у виробничий процес (утилізація).

Вплив функціонування АЗУ на атмосферне повітря оцінювався за результатами розрахунку розсіювання забруднювальних речовин у приземному шарі атмосфери, які були виконані за програмою «ЕОЛ+» відповідно до ОНД-86 «Методика расчёта концентраций в атмосферном воздухе вредных веществ, содержащихся в выбросах предприятий» (затверджена Держкомітетом СРСР по гідрометеорології і контролю природного середовища від 04.08.1986 р. №192; узгоджена Держбудом СРСР від 07.01.1986 p. №ДП-76-1; узгоджена МО3 СРСР 07.02.1986 p. №04-4/259-4). У розрахунках враховувались фонові показники забруднення атмосферного повітря в районі розміщення АБЗ.

Для АЗУ потужністю 50 тис. т/рік розрахункові показники не перевищували нормативних значень біля найближчого житла на відстанях 248-316 м від джерела викиду АЗУ і становили для основних забруднювальних речовин (у частках ГДК): суспендовані частинки, недиференційовані за складом 0,24-0,37; азоту діоксид - 0,33-0,40; вуглецю оксид - 0,1-0,12; вуглеводні граничні $\mathrm{C}_{12}-\mathrm{C}_{19}$ - 0,48-0,53; ксилол, фенол - 0,46-0,50.

Для АЗУ потужністю 23,1 тис. т розрахункові показники не перевищували нормативних значень біля найближчого житла на відстанях 300-310-330-350 м від джерела викиду АЗУ і становили для основних забруднювальних речовин (у частках ГДК): речовини у вигляді суспендованих твердих частинок (мікрочастинки та волокна) - 0,610,78 ; азоту діоксид - 0,13-0,14; вуглецю оксид - менше 0,10 ; вуглеводнів граничних $\mathrm{C}_{12}-\mathrm{C}_{19}-0,52-0,55$; ксилолу - 0,53-0,56; фенолу - 0,54-0,56, що не перевищує встановлених нормативів згідно 3 переліком «Гранично-допустимих концентрацій хімічних $\mathrm{i}$ біологічних чинників в атмосферному повітpi населених місць», затверджених т.в.о. Головного державного санітарного лікаря України 03.03.2015 та ГН 2.2.6.-184-2013 «Opiєнтовно безпечні рівні впливу (ОБРВ) забруднюючих речовин в атмосферному повітрі населених місць».

Фактичні показники забруднення атмосферного повітря для АЗУ потужністю 23,1 тис. т не перевищували нормативних значень біля найближчого житла на відстанях 300-310-330-350 м від джерела викиду АЗУ і становили для основних забруднювальних речовин (у частках ГДК): пилу - 0,150,42 ; азоту діоксид - 0,22-0,29; вуглецю оксид - 0,68-0,72; ангідриду сірчистого, ксилолу - менше 0,10 ; фенолу - 0,58-0,70.

За результатами оцінки, прогнозований рівень забруднення атмосферного повітря сельбищної території, найближче розташованої до основного джерела викидів (труби АЗУ), визначається як допустимий і безпечний.

Основним технологічним джерелом шуму на території АБЗ буде сушильний барабан АЗУ, який у вказаних установках, знаходиться в теплоізоляційному кожуху. Крім того, для зниження шуму пальник сушильного барабана також оснащений глушником, що поглинає шум при обертанні барабану. Прийняті технічні рішення, а також додаткові заходи з екранування акустичного впливу (огородження проммайданчика АБЗ, розміщення на шляху поширення звуку інших виробничих будівель та споруд, озеленення території підприємства та С33 з боку прилеглої 
житлової забудови тощо) забезпечують не

межі житлової забудови.

перевищення допустимих рівнів шуму на

\section{Висновки}

1. Створення нових і реконструкція (з модернізацією обладнання) асфальтобетонних заводів, як однієї з необхідних ланок системи будівництва і відновлення доріг України, $є$ надзвичайно актуальним питанням сьогодення. У цьому зв'язку проведення екологогігієнічної оцінки рівнів впливу цих об'єктів на умови проживання та здоров'я населення i якість довкілля з обгрунтуванням розмірів С33 є необхідною умовою безпеки їх функціонування.

2. Забезпечення безпеки функціонування АБЗ у містобудівних умовах, що історично склались, з урахуванням необхідності дотримання логістики від виробництва асфальтобетонних сумішей до їх кінцевого використання в дорожньому будівництві, повинно бути досягнуто шляхом впровадження і використання сучасних технічних і технологічних рішень, якісних сировинних матеріалів, високоефективного пилогазоочисного обладнання, режимів роботи устаткування, розроблення і впровадження додаткових захисних заходів планувального та технологічного характеру.

3. Умовою безпечного функціонування АБЗ у містобудівних умовах, що історично склались, є дотримання нормативних показників чинників шкідливого впливу на межі С33, яка встановлюється, як правило, по існуючій фактичній забудові, для чого необхідно проводити моніторингові дослідження, в першу чергу, за специфічними для даного виробництва речовинами.

\section{ЛІТЕРАТУРА}

1. Шавалюк Л. Будівництво доріг як національний проект // Український тиждень №18 (546) Режим доступу: http://nbuviap.gov.ua/index.

2. Будівництво доріг / Укравтодор. Режим доступу: http : // ukravtodor.gov.ua/timeline/6989.html.

3. Державні санітарні правила планування та забудови населених пунктів, затверджені Наказом МОЗУ від 19.06.1996 р. №173 // Зб. Важливих офіційних матеріалів з санітарних і протиепідемічних питань. - К., 1996. - Т.5. - Ч.1. - С. 6-93.

4. Оцінка впливу на довкілля процесів виготовлення асфальтобетону / А. Пінчук, О. Медведєва // Наукові записки. 2010. - Вип.10. - Ч.ІІІ. - С. 380-383.

\section{ЭКОЛОГО-ГИГИЕНИЧЕСКИЕ АСПЕКТЫ ФУНКЦИОНИРОВАНИЯ АСФАЛЬТОБЕТОННЫХ УСТАНОВОК В УКРАИНЕ В СОВРЕМЕННЫХ УСЛОВИЯХ ХОЗЯЙСТВОВАНИЯ}

Коваль Н.М.

Цель работы. Анализ градострочтельных условий размещения асфальтобетонных заводов (АБЗ) и урони вредных факторов влияния на безопасность жизнедеятельности населения и качества окружающей среды, которые создаются во время эксплуатации АБЗ.

Материалы и методы. Проанализированы параметры технологии производства асфальтобетона на мобильных асфальтосмешиваюших установках (АЗУ) производства Германии разной мощности (23,1 mblc. $m$ и 50 mblc. $m$ в год), размещенных в Черкасской и Волынской областях.

Санитарно-гигиеническую оценку уровней влияния на границе санитарно-защитной зоны (С33) проводили на основании результатов расчетных данных и натурных исследований проб атмосферного воздуха, уровней шума, предоставленных в протоколах специализированных аттестованных лабораторий. 
Результаты. АБЗ размещаются, как правило, на промплощадках, которые еще с советских времен функиионировали как предприятия по производству асфальтобетона. В настоящее время эти производства претерпевают реконструкичию с полной или частичной модернизацией оборудования или ведется новые строительство.

За результатами анализа, ни одна промплощадка не удовлетворяет требования приложения №4 к [3], поскольку за период организации этих производств на текущий период существенно изменились градостроительные условия, в которых не возможно организовать СЗ3 1000 м. Промплощчадки АБЗ, что рассматриваются, со всех сторон окружены существующей жилой застройкой, как правило, одно-, двухэтажной.

Для АЗУ (50 mblc. m/год) расчетные показатели не превышали нормативов возле близлежащих домов на расстоянии 248-316 м от источника выбросов АЗУ (в долях ПДК): твердые частицы, недифференцированные по составу - 0,24-0,37; азота диоксид - 0,330,40; углерода оксид - 0,1-0,12; углеводороды насыщенные $C_{12}-C_{19}-0,48-0,53$; ксилол, фенол - 0,46-0,50; для АЗУ (23,1 тыс. m/год) - на расстоянии 300-310-330-350 м от источника выбросов АЗУ (в долях ПДК): твердые частицы, недифференцированные по составу - 0,610,78; азота диоксид - 0,13-0,14; углерода оксид - меньше 0,10; углеводороды насыщенные $C_{12}-C_{19}-0,52-0,55 ;$ ксилол-0,53-0,56; фенол-0,54-0,56.

Фактические показатели загрязнения атмосферы для АЗУ (23,1 mblc. m/год) не превышали нормативов возле близлежащих домов на расстоянии 300-310-330-350 м от источника выбросов АЗУ (в долях ПДК): пыли - 0,15-0,42; азота диоксид - 0,22-0,29; углерода оксид-0,68-0,72; ангидрида сернистого, ксилола-меньше 0,10; фенола-0,58-0,70.

Bblводы. Безопасность функиионирования АБЗ должна бать обеспечена путем внедрения и использования современных технических и технологических решений, качественных сырьевых материалов, высокоэффективной пылегазоочистки, внедрения дополнительных защитных мероприятий планировочного и технологического характера с иелью не превышения нормативных уровней воздействия вредных факторов на границе СЗ3 и возле ближайшего жилья.

\title{
ENVIRONMENTAL AND HYGIENIC ASPECTS OF THE FUNCTIONING OF ASPHALT-CONCRETE INSTALLATIONS IN UKRAINE IN THE CURRENT CONDITIONS OF ECONOMIC EQUIPMENT
}

\author{
N.M. Koval
}

Objective. Analysis of urban planning conditions for the placement of asphalt concrete plants (ABZ) and the impact of harmful factors on the health of the population and the quality of the environment, which are created during the operation of ABZ.

Materials and methods. The parameters of the technology for the production of asphalt concrete on mobile asphalt mixing plants (AMS) produced in Germany of different capacities (23.1 thousand tons and 50 thousand tons per year) located in Cherkasy and Volyn regions are analyzed. Sanitary and hygienic assessment of the levels of influence at the boundary of the sanitary protection zone (SPZ) was carried out on the basis of the results of the calculated data and full-scale studies of atmospheric air samples, noise levels provided in the protocols of specialized certified laboratories.

Results. ABZ are located, as a rule, on industrial sites, which since Soviet times functioned as enterprises for the production of asphalt concrete. At present, these industries are undergoing reconstruction with full or partial modernization of equipment or new construction is underway. According to the results of the analysis, not a single industrial site satisfies the requirements of Appendix 4 to [3], since for the period of organizing these productions for the current period townplanning conditions have changed significantly, in which it is not possible to organize a SPZ $1000 \mathrm{~m}$. ABZ Industrial Site, which are considered from all sides surrounded by existing residential buildings, as a rule, one-, two-story. 
For the AMS (50 thousand tons / year), the calculated indicators did not exceed the standards near the nearby houses at a distance of 248-316 $\mathrm{m}$ from the source of emissions of the AMS (in terms of MPC): solid particles, undifferentiated in composition - 0.24-0.37; nitrogen dioxide 0.33-0.40; carbon oxide - 0.1-0.12; C12-C19 saturated hydrocarbons - 0.48-0.53; xylene, phenol 0.46-0.50; for the AMS (23.1 thousand tons / year) - at a distance of 300-310-330-350 m from the source of emissions of the AMS (in terms of MPC): solid particles, undifferentiated in composition - 0.61-0.78; nitrogen dioxide - 0.13-0.14; carbon oxide - less than 0.10; saturated hydrocarbons C12-C19-0.52-0.55; xylene - 0.53-0.56; phenol -0.54-0.56.

The actual indicators of air pollution for the AMS (23.1 thousand tons / year) did not exceed the standards near the nearby houses at a distance of 300-310-330-350 $\mathrm{m}$ from the emission source of the AMS (in terms of MPC): dust - 0.15-0,42; nitrogen dioxide - 0,22-0,29; carbon oxide - 0.680.72; sulfurous anhydride, xylene - less than 0.10; phenol -0.58-0.70.

Conclusions. The safety of the ABZ should be ensured through the introduction and use of modern technical and technological solutions, high-quality raw materials, highly efficient dust removal, the introduction of additional protective measures of a planning and technological nature in order not to exceed the regulatory levels of exposure to harmful factors at the border of the SPZ and near the nearest housing.

УДК 72.01:005+711.13:504

\title{
ПРОБЛЕМА ВІДХОДІВ В КОНТЕКСТІ РОЗВИТКУ УРБАНІЧСТИЧНОГО ПРОЦЕСУ
}

\author{
Трахтенгери Г.Я. ${ }^{1}$, Устінова I.I. $^{2}$ \\ 1.ДУ «Інститут громадського здоров'я ім. О.М. Марзєєва НАМН України», м. Київ \\ 2.Київський національний університет будівництва і архітектури, м. Київ
}

Вступ. Міста, що зароджувалися, були спочатку тимчасовими поселеннями малої кількості людей. Поступово, збільшуючись чисельно, розширюючись територіально, структурно та інформаційно ускладнюючись, ці поселення об'єднувалися $з$ іншими, утворюючи різні форми та системи населених міст. На сьогодні ці системи являють собою надскладні еколого-містобудівні системи «населення↔середовище», розвиток яких не можливо зрозуміти без знання загальних законів формування та розвитку систем оточуючого нас світу. Міста, як відображення форм життєвої активності людини, асимілюють в собі безмежну розмаїть соціальних та економічних процесів, матеріальнотехнічних засобів та естетичних ідеалів. Сьогодні місто $є$ домінуючим типом штучного просторового оточення людини, яке формується в процесі розвитку суспільства, як ще одна його «захисна оболонка». По відношенню до прилеглої території, місто виступає як цілісне утворення, що поглинає та пе- реробляє елементи свого оточення (сировинні та енергетичні ресурси, воду, повітря, тощо) й продукує у великій кількості різні види відходів (комунальні, виробничі, сільськогосподарські, відходи будівництва та споживання й інші). Ці особливості дозволяють розглядати міста як відкриті системи із рисами метаболізму - обміном речовиною, енергією та інформацією із зовнішнім середовищем, що $є$ основою існування та розвитку усіх природних систем [1-4].

Процес урбанізації в екологічній теоpiї проглядає у стратегії утворення безпечних поселень, за якою збирання в природному місті має для популяції свої переваги у вигляді підвищеної життєздатності групи (обумовлено кооперацією) та свої недоліки у вигляді стресів, які викликано переущільненням місць перебування, посиленням конкуренції за ресурси середовища, його забрудненням та деградацією $[1,2]$. Щодо метаболізму міст. В наш час на кожного мешканця планети в середньому на рік видобувається 